\title{
Restitución de las villas no construidas de Le Corbusier en India mediante la mirada de Lucièn Hervè
}

\author{
Eduardo Carazo \\ Álvaro Moral \\ David Mahamud
}

\section{Resumen}

A mediados del siglo XX Le Corbusier es requerido por el gobierno de la India para la construcción de la nueva ciudad de Chandigarh. L.C. adaptó su arquitectura moderna tomando ciertos elementos de la arquitectura del lugar y creando así una tipología bioclimática avanzada a su tiempo.

Lucien Hervé, uno de los maestros de la fotografía de arquitectura del siglo $X X$, acompañó a Le Corbusier durante los últimos 15 años de su carrera, contribuyendo decisivamente a la difusión de su arquitectura.

Las villas Hutheesing y Chimanbhai predecesoras de la sí construida villa Shodhan, fueron dos proyectos que de Le Corbusier que no llegaron a realizarse, aunque contribuyeron a materializar la trayectoria del arquitecto.

Este trabajo se ha llevado a cabo estableciendo una relación entre diferentes artes y técnicas, con el fin de reinterpretar la visión conjunta que supone el resultado de dos grandes artistas y maestros en su ámbito, trabajando al unísono.

La restitución virtual nos permite recrear arquitecturas que no llegaron a materializarse y que, habiendo supuesto un hito en la carrera del arquitecto que las diseñó, finalmente puedan ahora salir a la luz y ser difundidas, de la misma manera en la cual la fotografía acompañó desde sus orígenes a la arquitectura como nuevo lenguaje figurativo para su difusión en la distancia.

Nuevas técnicas infográficas se unen aquí al lenguaje propio de la fotografía, a la mirada del fotógrafo, para hacer llegar hasta nosotros el conocimiento de unas arquitecturas ausentes, distantes en el tiempo.

\section{Palabras clave}

infografía, fotografía, arquitecturas ausentes, Le Corbusier.

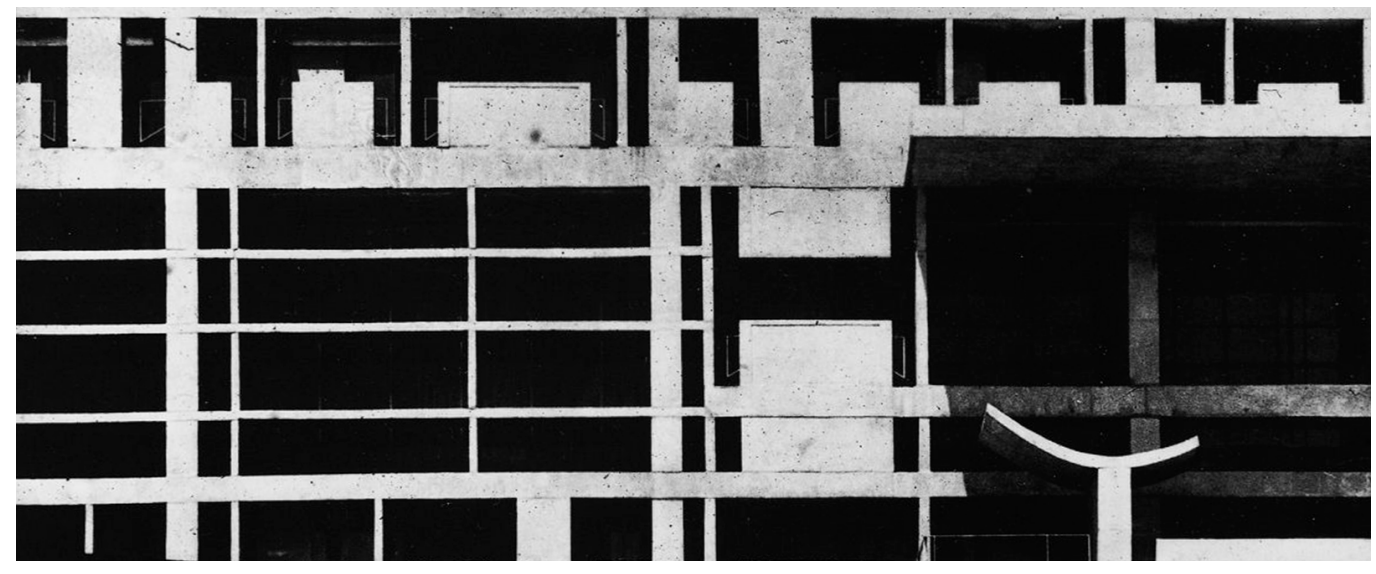




\section{Introducción}

Normalmente, un porcentaje muy bajo de los proyectos de arquitectura es finalmente construido. Son inusuales los casos en los que un diseño inicial, que no ha llegado a realizarse, llega a trascender. Generalmente, los proyectos no realizados desaparecen o se olvidan sin llegar jamás a ser reconocidos. Pero también, acaban formando parte fundamental de la carrera y de la evolución del estilo del propio arquitecto e, incluso de un movimiento o una generación. Antes de ser construida, la arquitectura tiene la cualidad de poder ser vista sin existir plenamente y ser discutida cuando se encuentra aún en papel. Puede, por lo tanto, influir en la evolución del pensamiento de un colectivo, de una sociedad, sin haber siquiera llegado a existir, e incluso puede proponernos nuevos modos de utilizar nuestro entorno, aún sin haberlo modificado todavía (fig. I).

¿Tienen derecho las propuestas que no se materializan a ser consideradas como arquitectura? ¿Podemos considerar la arquitectura no construida como arquitectura? En muchas ocasiones las ideas que representan algunos proyectos pueden ser tan influyentes e inspiradoras como muchas estructuras terminadas.

En la sociedad actual, acostumbrada a 'ver' y convertida en una gran consumidora de imágenes, la expresión popular "vale más una imagen que mil palabras" gana sentido; aunque no esté considerada como una de las "bellas artes", la fotografía es una disciplina que va ligada muy estrechamente a la arquitectura, permitiéndonos conocerla sin tener que visitarla y a la vez poniéndola en valor; de tal manera que hoy en día no podríamos concebir la una sin la otra, aunque quedando siempre relegada a un segundo plano en el territorio creativo.

Lucien Hervé, fotógrafo de arquitectos fue, durante toda su vida, la estrella eclipsada por los titanes de la arquitectura a los que acompañó, y cuya obra propulsó gracias a su fotografía. Le Corbusier pudo contar con él y Hervé se implicó en su arquitectura y supo destacar cada detalle con su particular mirada (fig. 2).

Con esta investigación se pretende completar la colección de villas que Le Corbusier proyectó para la India pero que no fueron construidas, haciendo de las nuevas técnicas infográficas un lenguaje novedoso para acercarnos a esas arquitecturas ahora ausentes, para de algún modo, minimizar la distancia que el tiempo y su ausencia interponen. La mirada del fotógrafo nos permitirá relacionar ese lenguaje infográfico, tan difícil de definir, con una metodología narrativa muy desarrollada y coherente.

Según Martin Heidegger,"todo proyecto no construido es una ruina"; por lo que la "no ejecución" se transforma aquí,"en una destrucción silenciosa y silenciada, en una explosión que, en este caso, implosiona" [González 20 I3, p. 3].Y es precisamente por esto que la ambición de este trabajo reside en la relación que el arquitecto tenía con su fotógrafo, la cual vamos a explotar para estudiar y recrear estas villas no construidas.

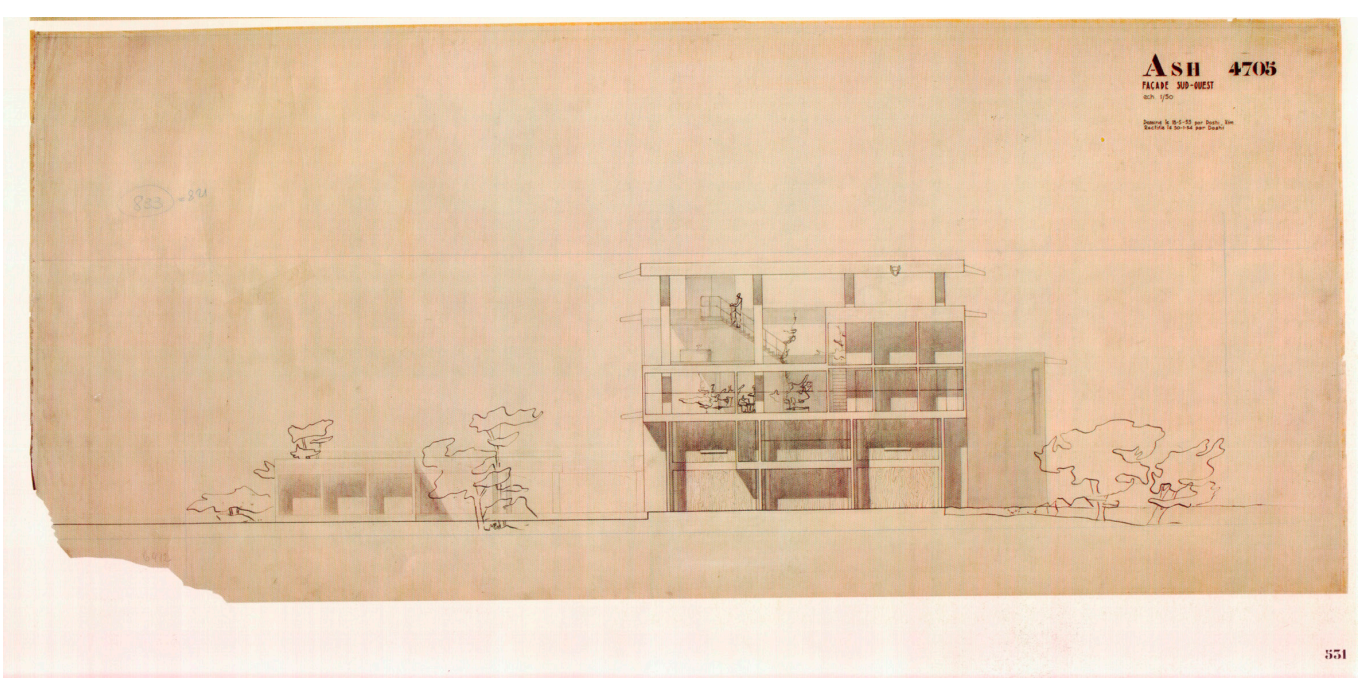




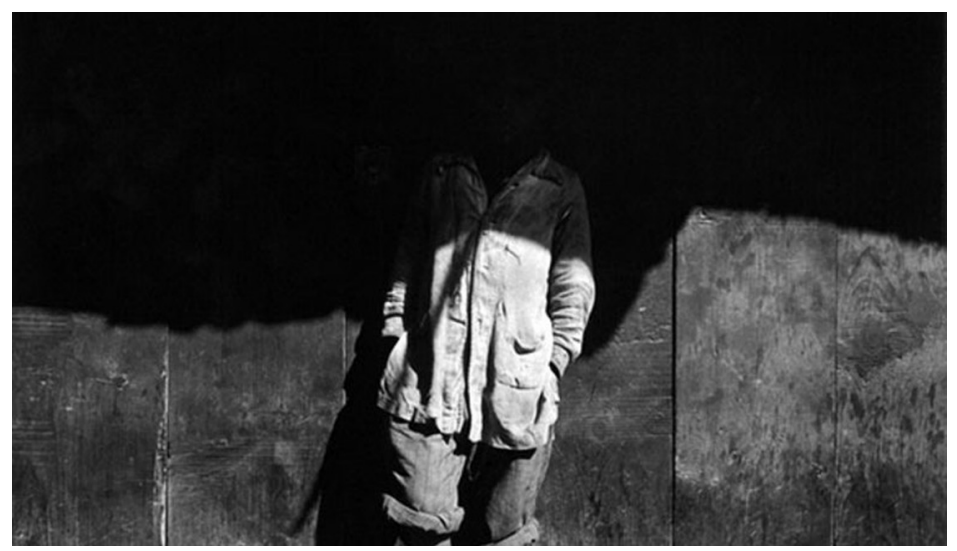

\section{Le Corbusier en la India}

Los países occidentales no le dieron a Le Corbusier la oportunidad que le brindó la India para desarrollar plenamente sus principios sobre la arquitectura y la ciudad modernas. Este país, pobre y atrasado tecnológicamente, encargó al arquitecto los complejos más monumentales y su plan urbanístico más completo: El trazado urbanístico de la recién fundada ciudad de Chandigarh y cuatro importantes edificios gubernamentales, de los que a su vez surgieron varios proyectos domésticos para Ahmedabad, que serán objeto de esta investigación.

Le Corbusier fue invitado a visitar Ahmedabad a las pocas semanas de su llegada a la India en 195I. Acabaría construyendo en esta ciudad un museo, el edificio de la Asociación de Hilanderos, una vivienda para el Sr. Shodhan y una casa más pequeña para la señora Manorama Sarabhai. Con estos encargos, mucho más modestos que los de la capital del Punjab, aprovechó para experimentar acerca de lo que él llamaba "arquitectura para los tiempos modernos adaptada al clima de la India" [Curtis 1987, p. 202]. Estamos, pues, ante una arquitectura bioclimática muy avanzada a su tiempo, y por lo demás, muy contemporánea. Le Corbusier estudió y dibujó la arquitectura vernácula y extrajo de ella sus fundamentos, [Curtis 1987, pp. I88-20 I] combinando después estas enseñanzas con los principios de su propia arquitectura. Buscaba una "gramática india moderna y básica" [Curtis 1987, p. 191] que se caracterizó por la utilización de hormigón, además de elementos como la cubierta volada o parasol y el brise-soleil, empleados junto con gruesos pilares apantallados (fig. 3).

\section{Lucien Hervé}

Lucien Hervé (fig. 4) es uno de los maestros de la fotografía de arquitectura del siglo XX. Colaboró con arquitectos como Breuer, Niemeyer, Gropius, Aalto, Nervi, Prouvé, o el propio Le Corbusier a lo largo de su extensa carrera profesional.

Su verdadero nombre fue László Elkán. Nació en Budapest en 1910, donde vivió hasta que comenzó su formación artística en Viena, con 18 años, acudiendo asiduamente a la facultad de Bellas Artes donde recibe clases de dibujo. Aunque fue en París, dos años después, donde dio el salto al mundo del arte y se hizo representante y diseñador de moda. Pero no fue hasta 1938 cuando comenzó a trabajar como reportero fotográfico en la revista Marianne Magazine bajo el seudónimo de Müller.

Su relación con el arquitecto franco-suizo comienza en 1949, cuando su entonces editor Alain Coututier, le recomienda que vaya a ver la obra de Le Corbusier. Hervé se desplaza para visitar la Unidad de Habitación de Marsella y queda fascinado. Realiza un extenso reportaje fotográfico que posteriormente envía al propio Le Corbusier, quien quedó muy impresionado con el trabajo:"Tienes alma de arquitecto", [Andrieux 20 I I, p. I2] le dijo. A partir de ese momento, su carrera profesional se centraría totalmente en la fotografía de arquitectura, convirtiéndose en el fotógrafo de Le Corbusier hasta la fecha de su muerte en 1965. 
Fig. 3.Villa Shodhan, Lucien Hervé. (C) Lucien Hervé.

Fig. 4. Autorretrato de Lucien Hervé. (c) Lucien Hervé.

Fig. 5. Claroscuros en la obra de Lucien Hilanderos, Le Corbusier. Ahmedabad (India), 1951. (C) Lucien Hervé.

Fig. 6. Detalle de la cubierta de la iglesia de Ronchamp, Lucien Hervé. (c) Lucien Hervé
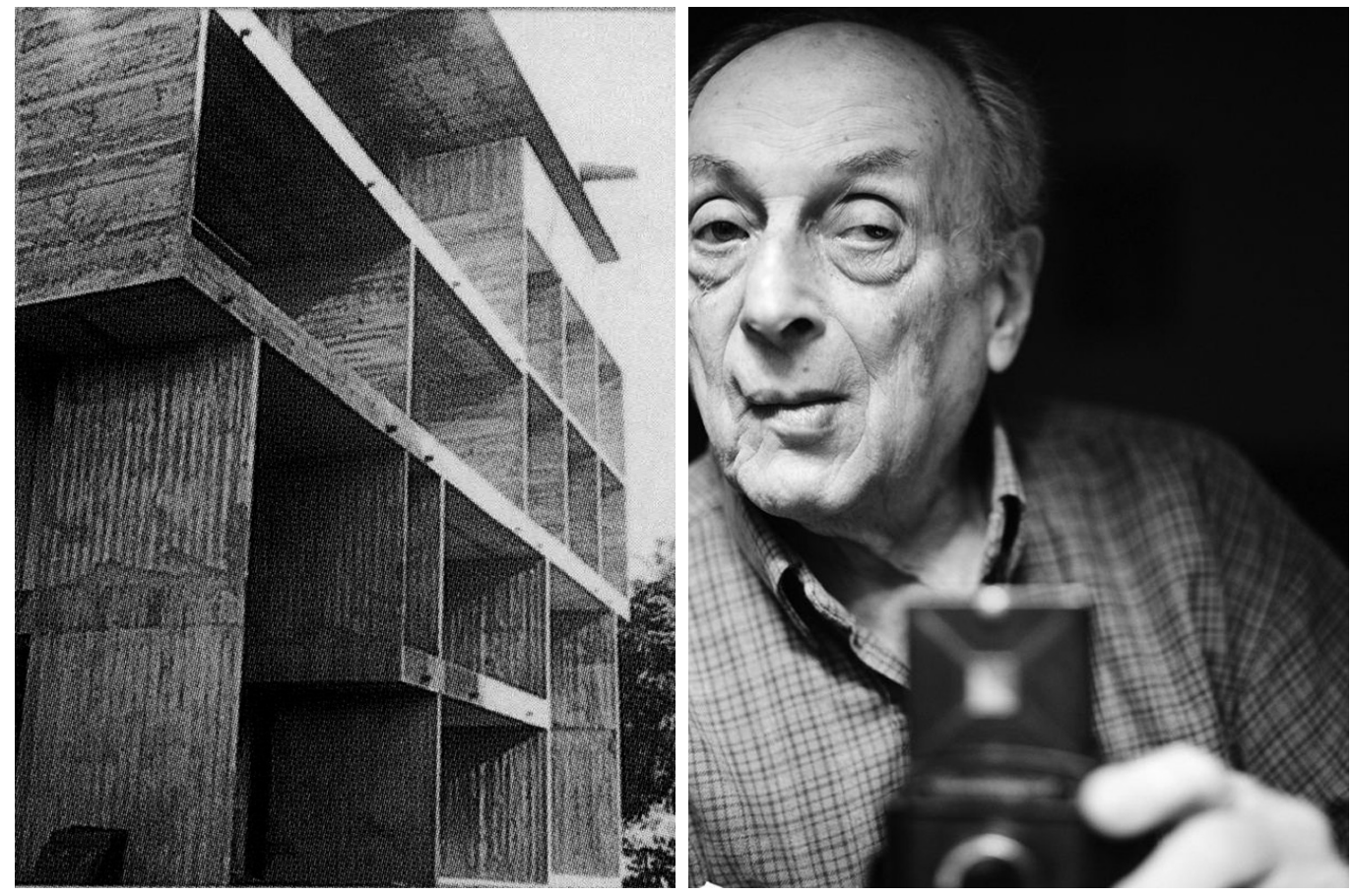

Hervé, alcanzados ya los 60 años, cesa la intensa actividad laboral por un problema de salud y se dedica a viajar y a realizar pequeños encargos. Muere el 26 de junio de 2007 en París, con 96 años, dejando tras de sí una valiosa obra que va más allá de la arquitectura.

\section{La fotografía de Lucien Hervé}

Famoso, como él mismo decía, por su rigor, y conocido por la fotografía de claroscuros (fig. 5) y los encuadres extravagantes que realizaba a punta de tijera, en una entrevista en 1992 declara: "Siempre fotografié de tal manera que una fotografía debería poder verse invertida. Porque para nosotros no es el tema lo que es importante, no es el sujeto, sino esencialmente la expresión plástica", [Bergera 2016 , transcripción de documental] también afirmaba que "la estructura plástica de una foto es el elemento esencial para introducir tensión interior. Sin una exigente y rigurosa composición, una fotografía no es más que una anécdota o un reportaje" [Bergera 20 16, transcripción de documental]
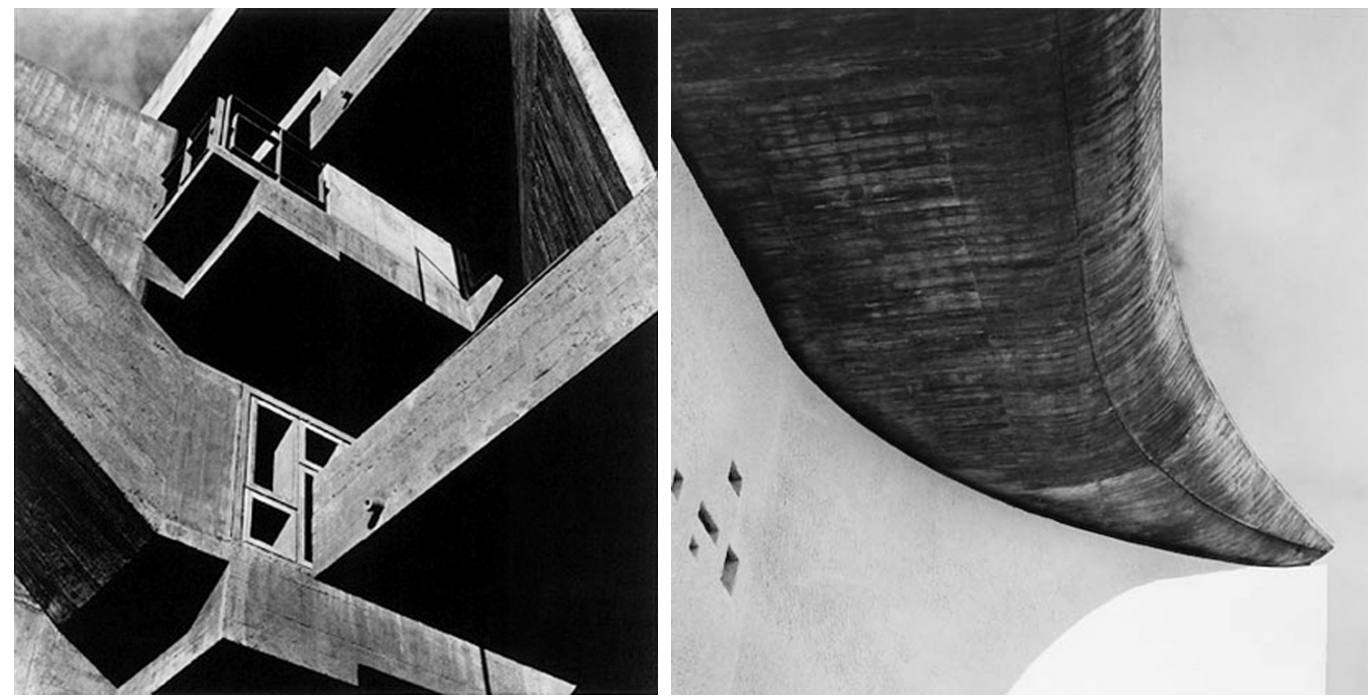
La fotografía de Lucien Hervé no podemos tomarla como una simple documentación de los elementos fotografiados, sino que lo realmente atractivo de su labor reside en la lectura personal que hace del trabajo del arquitecto. De manera que, cuando observamos su obra, además de reconocer el elemento fotografiado, estamos realizando el acto de mirar como si del mismo Hervé se tratara (fig. 6).

Cuando Hervé llegaba a su estudio después de un día de trabajo, revelaba las fotografías realizadas, las clasificaba y escogía las mejores. Éstas, las pegaba encima de una cartulina y las cortaba a su antojo, dejando sólo la parte que más le interesaba, abstrayéndose así del edificio, pero poniéndolo en valor a su vez, haciéndolo desaparecer como objeto y transformándolo en un paisaje abstracto. Él mismo decía que su principal virtud era el rigor y, de la misma forma que un escultor va descubriendo la escultura sustrayendo piedra de un bloque, Hervé utiliza la que llamaba autocrítica con tijeras, para eliminar lo superfluo en cada encuadre.

Con el resultado final, confeccionaba álbumes, pegando las imágenes recortadas creando una secuencia compositiva, como si de una promenade architectural en base fotográfica se tratase. Dentro de la imposibilidad de fotografiar el movimiento, los fotógrafos de arquitectura no plasman instantes sino lapsos, siendo la representación, dentro de la paradoja de la fotografía estática, de "un recorrido para la mirada que evoque en cierta medida la percepción espacial real de la escena representada" [Bergera 20 I6, p. I 36]. Así, la esencia de la serie de fotografías, está relacionada directamente con el espacio fotografiado, siendo la relación entre las fotografías de la propia secuencia la que nos muestra la naturaleza del proyecto. Hervé era uno de esos fotógrafos inusuales con alma de arquitecto. Su singular forma de retratar los edificios, huyendo de la monumentalidad y de las simetrías, su peculiar estilo de imágenes recortadas, de picados y contrapicados, juegos de sombras, vistas oblicuas que acaban en encuadres con una fuerte perspectiva y composiciones abstractas, era lo que le hacía destacar de entre sus contemporáneos.

Existen innumerables imágenes representativas del trabajo de Hervé. Pero su importancia, dejando de lado la mera imagen, es lo que representa. Su esencia radica en la forma de un referente arquitectónico, cuya naturaleza fotográfica se manifiesta en un esquema de extrema simpleza que destaca su configuración mediante un juego de luz y sombra que el fotógrafo utiliza en muchas ocasiones de un modo deconstructivo, dirigiéndonos a ámbitos visuales más complejos y densos.

\section{El lenguaje infográfico entre el tiempo y la distancia}

Las villas Hutheesing y Chimanbhai fueron dos encargos que recibió Le Corbusier para realizar dos viviendas en Ahmedabad. La primera a cargo del presidente de la asociación de hilanderos Surottam Hutheesing y, la segunda, a cargo del alcalde de la propia ciudad de Ahmedabad. Ninguno de los dos se llevó a cabo.

En los proyectos para las villas Hutheesing y Chimanbhai destacan las fachadas de brise-soleil, el famoso paraguas que vuela y cubre la construcción y, también, la sobria geometría exterior que encierra una dinámica sección resultado de un juego interior de volúmenes que vuelan creando patios de diferentes alturas.

Ambos diseños eran variaciones sobre la misma idea básica, volúmenes cúbicos perforados por profundas aberturas para el aire y la sombra, y enormes parasoles horizontales flotantes para proteger del sol y de la lluvia: Lo que hoy en día llamaríamos sistemas pasivos de una construcción sostenible. Le Corbusier componía las fachadas disponiendo los brise-soleil según las proporciones del Modulor, diseñaba las partes inferiores de las viviendas bajas y sombrías y, a medida que ibas subiendo, el edificio se iba abriendo hacia el cielo y el entorno. El brise -soleil y los paños ciegos de las fachadas, con sus geometrías ortogonales, resaltaban ante los serpenteantes recorridos interiores y ante los puntuales elementos ovalados.

Los diseños para las residencias Chimanbhai (figg. 7, 9, I I) y Hutheesing (figg. 8, I0, 12) intentaban dar también una presencia monumental ennobleciendo el programa doméstico. Ambos diseños eran variaciones sobre la misma idea básica, volúmenes cúbicos perforados 
Fig. 7.Villa Chimanbhai, Le Corbusier. Ahmedabad (India), 1951. Restitución gráfica de los autores.

Fig. 8. Villa Hutheesing, Le Corbusier. Ahmedabad (India), 1951. Restitución gráfica de los autores.
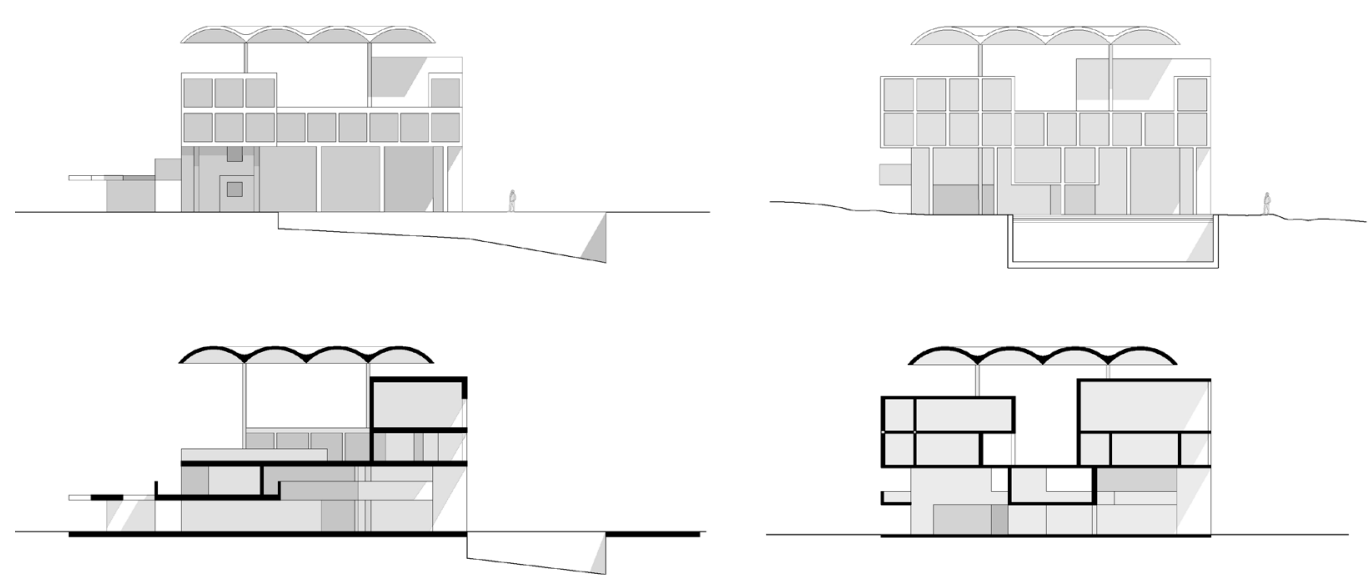

por profundas aberturas para el aire y la sombra, y enormes parasoles horizontales flotantes para proteger del sol y de la lluvia.

Le Corbusier componía las fachadas disponiendo los brise-soleil según las proporciones del Modulor, diseñaba las partes inferiores de las viviendas bajas y sombrías y, a medida que ibas subiendo, el edificio se iba abriendo hacia el cielo y el entorno. El brise-soleil y los paños ciegos de las fachadas, con sus geometrías ortogonales, resaltaban ante los serpenteantes recorridos interiores y ante los puntuales elementos ovalados.

Fueron varios los motivos por los cuales estas villas nunca llegaron a realizarse, pero, Le Corbusier rescató ambos proyectos buscando inspiración para realizar el diseño de la villa Shodhan.

Hoy en día los medios digitales utilizados en el ámbito de la arquitectura han evolucionado enormemente. Para la realización de este trabajo previamente se ha hecho una recopilación de información de la obra de Le Corbusier en la India. De esta documentación se han seleccionado croquis, textos y, sobre todo, planos para elaborar una serie de levantamientos de las villas a representar. Una vez disponemos de los levantamientos se efectúa un modelo en 3D de los edificios con el mismo programa de CAD con el que habíamos elaborado los planos en 2D.

Después de esto, el modelo se exporta a un programa de creación de gráficos y animación 3D. Dicho programa se utiliza para crear la escena que posteriormente será nuestra fotografía. Por lo tanto, se diseñan y aplican los materiales de los cuales está compuesto el modelo, basándonos en los edificios ya construidos del arquitecto, se colocan los elementos y luces necesarios del paisaje para dar mayor verosimilitud a la imagen y se colocan las cámaras, buscando las mejores perspectivas y encuadres, intentando simular la fotografía del propio Hervé. Finalmente, retocando ligeramente la imagen resultante mediante un programa de postproducción, podemos obtener la 'fotografía' que buscábamos.
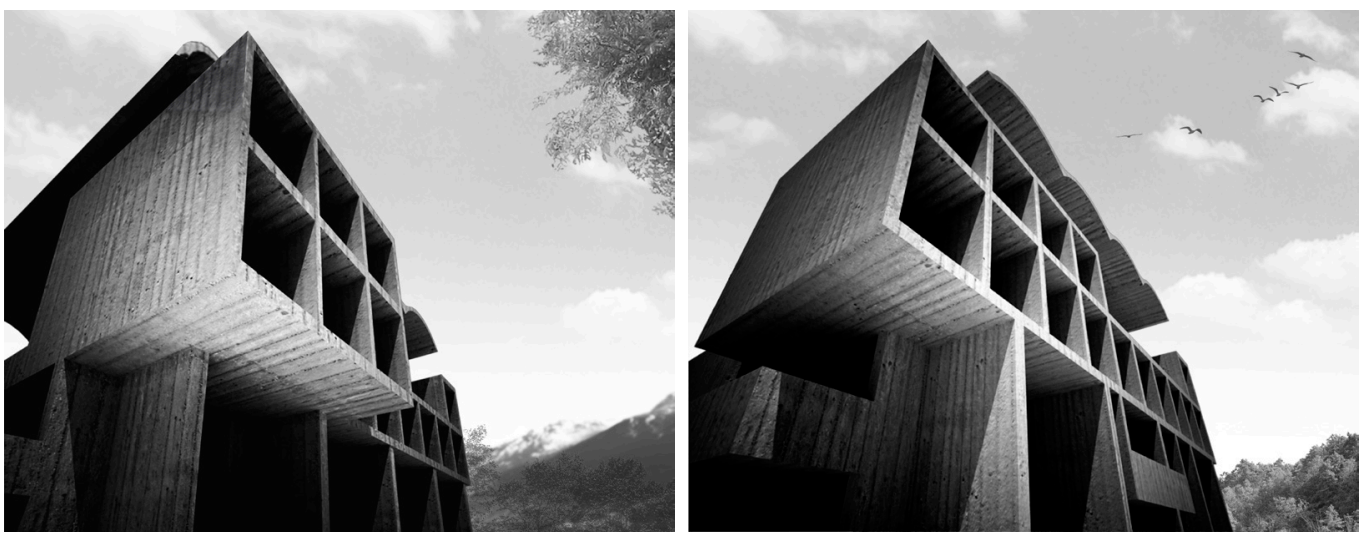

Fig. 9.Villa Chimanbhai infografía de los autores. 
Fig. I I. Interior villa Chimanbhai, infografía de los autores.

Fig. 12. Interior villa Hutheesing, infografía de los autores.
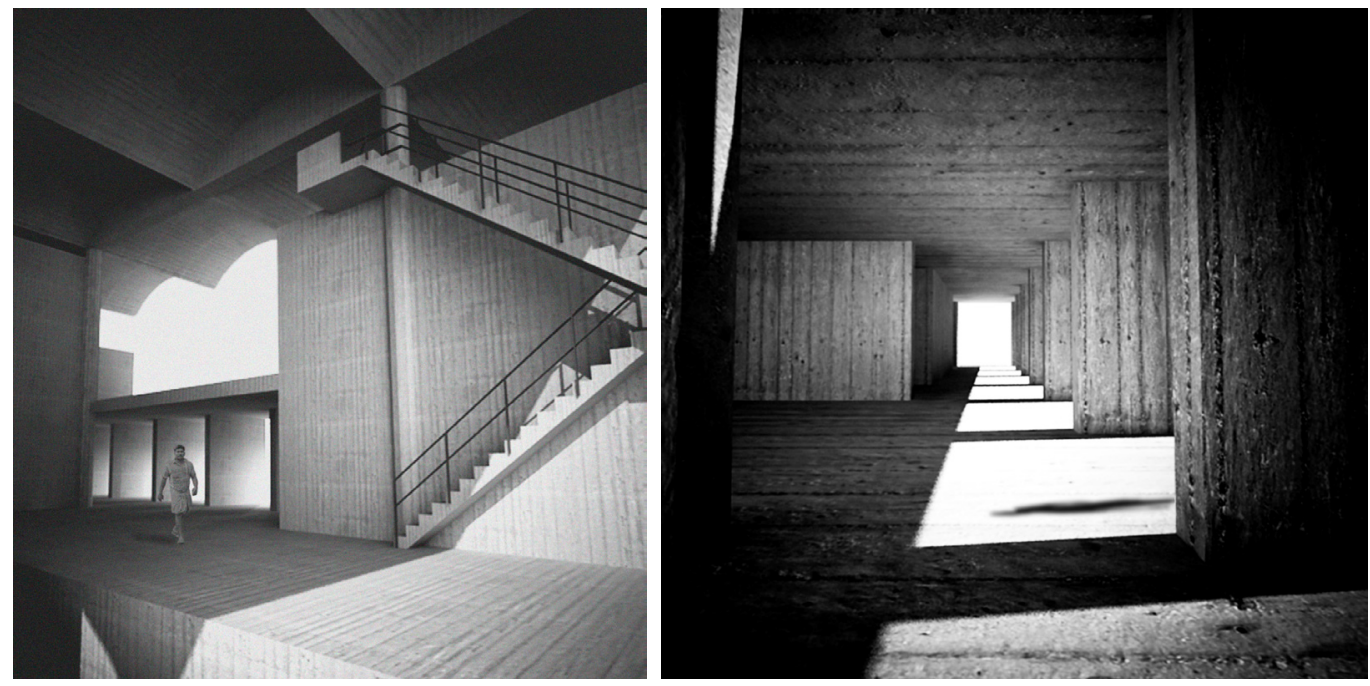

\section{Conclusiones}

Como la tecnología (la infografía) nos permite acercarnos mediante el lenguaje gráfico, a la distancia que nos introduce el tiempo y la arquitectura no construida, y hacerla para nosotros tangible y contemporánea mediante las imágenes y los planos levantados.

Hacemos así una contribución al conocimiento de esas arquitecturas no construidas, tanto desde el rigor de la métrica y la representación más convencional de la arquitectura, como de las nuevas tecnologías infográficas, que tensamos para acercarnos a esas genuinas visiones del fotógrafo que el propio arquitecto escogió para difundir su obra.

Como la fotografía sirvió desde sus orígenes en el siglo XIX como nueva tecnología y nuevo lenguaje para hacer llegar la arquitectura a lo largo del mundo, acortando distancias y acercando culturas, utilizamos ahora esa fotografía virtual de lo inexistente, para fotografiar, a través de la mirada privilegiada de Lucièn Hervè, las villas no construidas de Le Corbusier en la India.

\section{Referencias}

Ando T. (200 I). Le Corbusier: Houses. Tokyo:Toto.

Andrieux B. (20I I). Le Corbusier - Lucien Hervé, Kontakte. Munich: Schirmer Mosel.

Benton T. (1984). Les villas de Le Corbusier. París: P. Sers.

Bergera I. (2016a). Lucien Hervé: fotógrafo a su pesar. Barcelona: Arquia.

Bergera I. (20 I 6b). Sobre fotografía y arquitectura. Madrid: Ediciones Asimétricas.

BoesigerW. (1995). Le Corbusier. Oeuvre complète. 8 vols. Zurich: Girsberger.

Curtis W. J. R. (1987). Le Corbusier, ideas y formas. Madrid: Blume.

Frampton K. (2000). Le Corbusier. Madrid: Editore Akal.

Gonzalez D. (6 de mayo de 20 I3). Le Corbusier:The last proyect. Metalocus. <https://www.metalocus.es/es/noticias/dionisio-gonzalez-le-corbusier-last-project> (visitado el 7 de julio de 2021 ).

Le Corbusier. (1965). Hacia una arquitectura. Buenos Aires: Poseidón. Titulo original: Vers une Architecture, 1923.

\section{Autores}

Eduardo Carazo, Universidad de Valladolid, eduardo.carazo.lefort@uva.es

Álvaro Moral, Universidad de Valladolid, alvaro.moral@uva.es

David Mahamud, Universidad de Valladolid, david.mahamud@alumnos.uva.es

Para citar este capítulo: Carazo Eduardo, Moral Álvaro, Mahamud David (2021). Restitución de las villas no construidas de Le Corbusier en India mediante la mirada de Lucièn Hervè/Restitution of Le Corbusier's Unbuilt Villas in India through the eEyes of Lucièn Hervè. In Arena A. Arena M. Mediati D. Raffa P (a cura di). Connettere. Un disegno per annodare e tessere Linguagri Distanze Tecnologie. Atti del $42^{\circ}$ Convegno Internazionale dei Docenti delle Discipline della Rappresentazionel Connecting. Drawing for weaving relationship Langueges Distances Technologies Proceedings of the 42 th International Conference of Representation Disciplines Teachers. Milano: FrancoAngeli, pp. $2137-2150$. 


\title{
Restitution of Le Corbusier's Unbuilt Villas in India through the Eyes of Lucièn Hervè
}

\author{
Eduardo Carazo \\ Álvaro Moral \\ David Mahamud
}

\section{Abstract}

In the mid-twentieth century Le Corbusier is required by the government of India for the construction of the new city of Chandigarh. L.C. adapted his modern architecture by taking certain elements of the local architecture and creating a bioclimatic typology ahead of its time.

Lucien Hervé, one of the masters of architectural photography in the 20th century, accompanied Le Corbusier during the last 15 years of his career, contributing decisively to the diffusion of his architecture. The Hutheesing and Chimanbhai villas, predecessors of the villa Shodhan, were two of Le Corbusier's projects that were never realized, although they contributed to materialize the architect's career. This work has been carried out by establishing a relationship between different arts and techniques, in order to reinterpret the joint vision that is the result of two great artists and masters in their field, working in unison.

Virtual restitution allows us to recreate architectures that never materialized and that, having been a milestone in the career of the architect who designed them, can now finally come to light and be disseminated, in the same way in which photography accompanied architecture from its origins as a new figurative language for its dissemination in the distance.

New infographic techniques join here to the language of photography itself, to the photographer's gaze, to bring to us the knowledge of absent architectures, distant in time.

\section{Keywords}

infographics, photography, absent architectures, Le Corbusier.

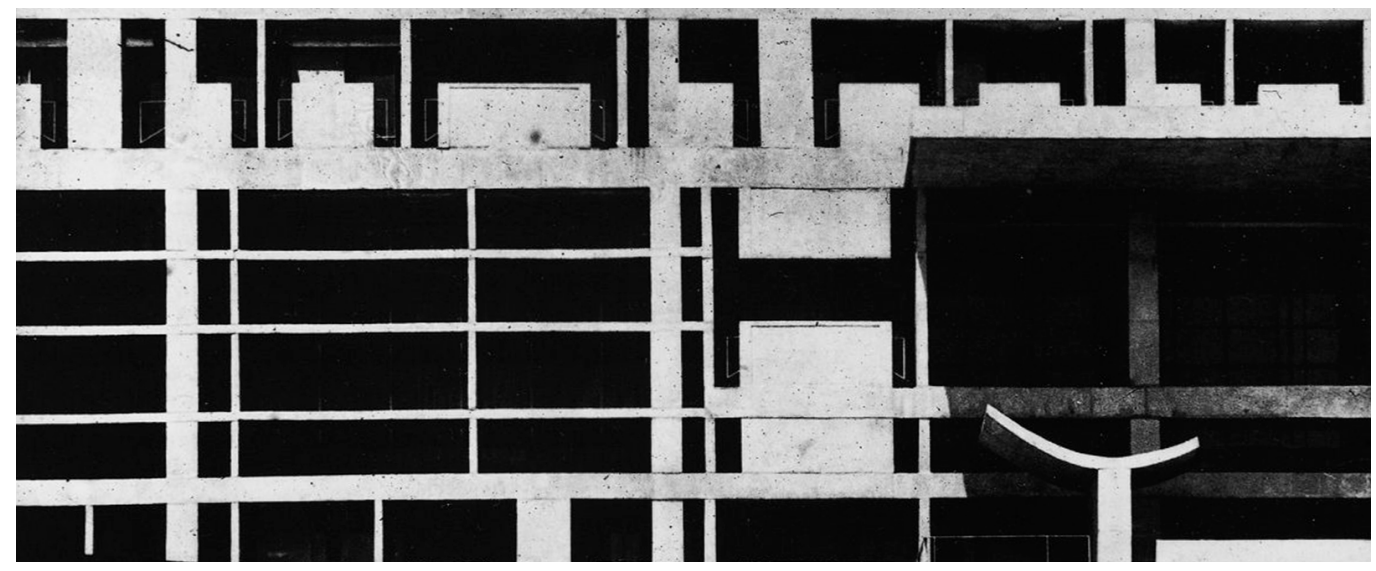




\section{Introduction}

Normally, a very low percentage of architectural projects are finally built. It is unusual for an initial design, which has not been realized, to be transcended. Generally, unrealized projects disappear or are forgotten without ever being recognized. Nevertheless they also end up forming a fundamental part of the career and the evolution of the architect's own style, and even of a movement or a generation. Before being built, architecture has the quality of being able to be seen without fully existing and to be discussed while still on paper. It can, therefore, influence the evolution of the thinking of a collective, of a society, without even having come into existence, and can even propose new ways of using our environment, even without having modified it yet (fig. I).

Do proposals that do not materialize have the right to be considered architecture? Could we consider unbuilt architecture as architecture? On many occasions, the ideas represented by some projects can be as influential and inspiring as many finished structures.

In today's society, accustomed to 'seeing' and converted into a great consumer of images, the popular expression "a picture is worth a thousand words" gains meaning; although it is not considered as one of the "fine arts", photography is a discipline that is closely linked to architecture, allowing us to know it without having to visit it and at the same time putting it in value; so that today we could not conceive one without the other, although always relegated to the background in the creative territory.

Lucien Hervé, photographer of architects was, throughout his life, the star eclipsed by the titans of architecture that he accompanied, and whose work was boosted thanks to his photography. Le Corbusier could count on him and Hervé became involved in his architecture and knew how to highlight every detail with his particular gaze (fig. 2).

This research aims to complete the collection of villas that Le Corbusier designed for India but that were not built, using new computer graphics techniques as a new language to bring us closer to those architectures that are now absent, in order to somehow minimize the distance that time and their absence interpose. The photographer's gaze will allow us to relate this infographic language, so difficult to define, with a highly developed and coherent narrative methodology.

According to Martin Heidegger, "every unbuilt project is a ruin"; therefore, the "non-execution" is transformed here, "into a silent and silenced destruction, into an explosion that, in this case, implodes" [González 20 I3, p. 3]. And it is precisely for this reason that the ambition of this work lies in the relationship that the architect had with his photographer, which we will exploit to study and recreate these unbuilt villas.

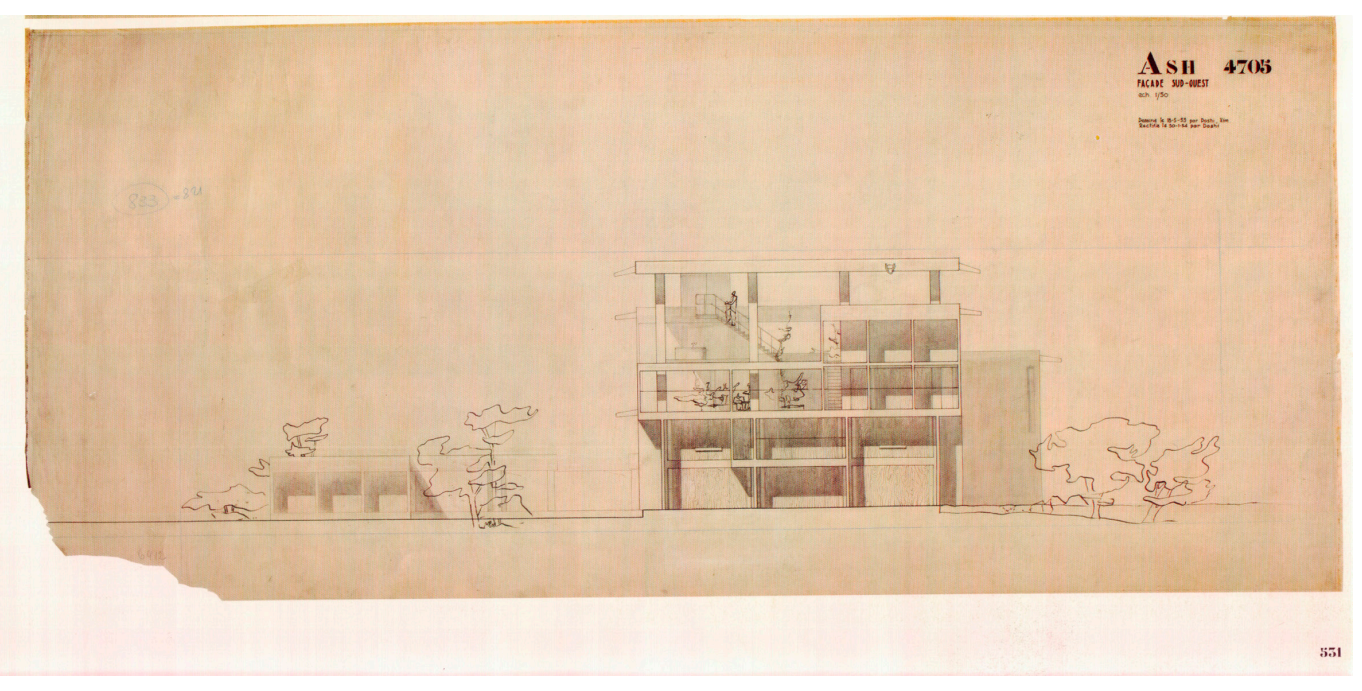




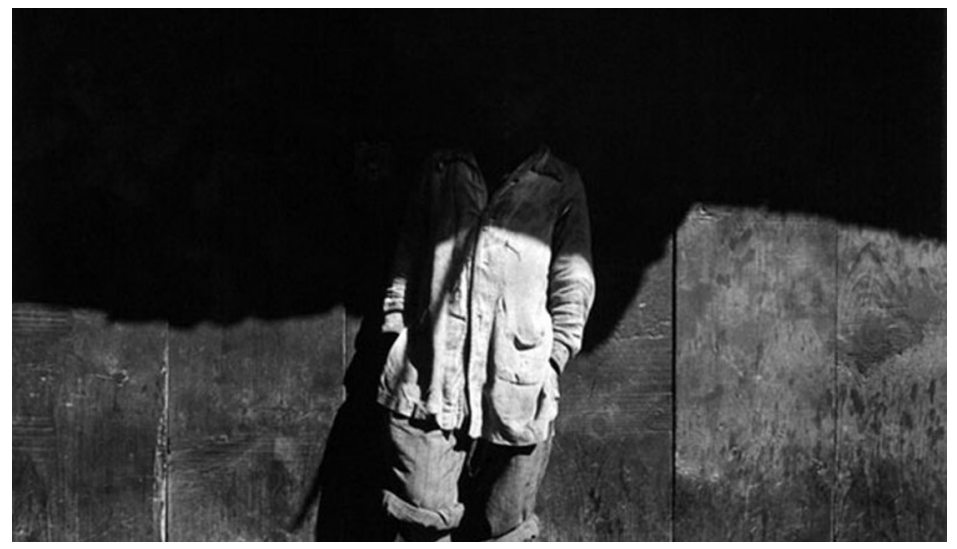

\section{Le Corbusier in India}

Western countries did not give Le Corbusier the opportunity that India gave him to fully develop his principles of modern architecture and the modern city. This poor and technologically backward country commissioned the architect's most monumental complexes and his most complete urban plan: the urban layout of the newly founded city of Chandigarh and four important government buildings, from which in turn emerged several domestic projects for Ahmedabad, which will be the subject of this research.

Le Corbusier was invited to visit Ahmedabad within weeks of his arrival in India in 195I. He would end up building in this city a museum, the Spinners Association building, a house for Mr. Shodhan and a smaller house for Mrs. Manorama Sarabhai. With these commissions, much more modest than those in the capital of the Punjab, he took the opportunity to experiment with what he called "architecture for modern times adapted to the Indian climate" [Curtis 1987, p. 202]. We are, then, faced with a bioclimatic architecture well ahead of its time and very contemporary.

Le Corbusier studied and sketched vernacular architecture and drew from it, its fundamentals, [Curtis 1987, pp.|88-20I] later combining these teachings with the principles of his own architecture. He sought a "modern, basic Indian grammar" [Curtis 1987, p. I9I] that was characterized by the use of concrete, in addition to elements such as the cantilevered roof or parasol and brise-soleil, employed in conjunction with thick shielded pillars (fig. 3).

\section{Lucien Hervé}

Lucien Hervé (fig. 4) is one of the masters of architectural photography in the 20th century. He collaborated with architects such as Breuer, Niemeyer, Gropius, Aalto, Nervi, Prouvé, or Le Corbusier himself throughout his extensive professional career.

His real name was László Elkán. He was born in Budapest in 1910, where he lived until he began his artistic training in Vienna, at the age of 18 , attending regularly to the Faculty of Fine Arts where he received drawing classes. Although it was in Paris, two years later, where he made the leap to the art world and became a representative and fashion designer. However it was not until 1938 when he began working as a photojournalist for Marianne Magazine under the pseudonym Müller.

His relationship with the French-Swiss architect began in 1949, when his then editor, Alain Coututier, recommended that he go to see Le Corbusier's work. Hervé went to visit the Unité d'Habitation in Marseille and was fascinated. He made an extensive photographic report that he later sent to Le Corbusier himself, who was very impressed with the work: "You have the soul of an architect", [Andrieux 20 I I, p. I2] he told him. From that moment on, his professional career would focus entirely on architectural photography, becoming Le Corbusier's photographer until the date of his death in 1965. 
Fig. 3. Villa Shodhan Lucien Hervé. (C) Lucien Hervé.

Fig. 4. Self portrait of Lucien Hervé. @ Lucien Hervé.
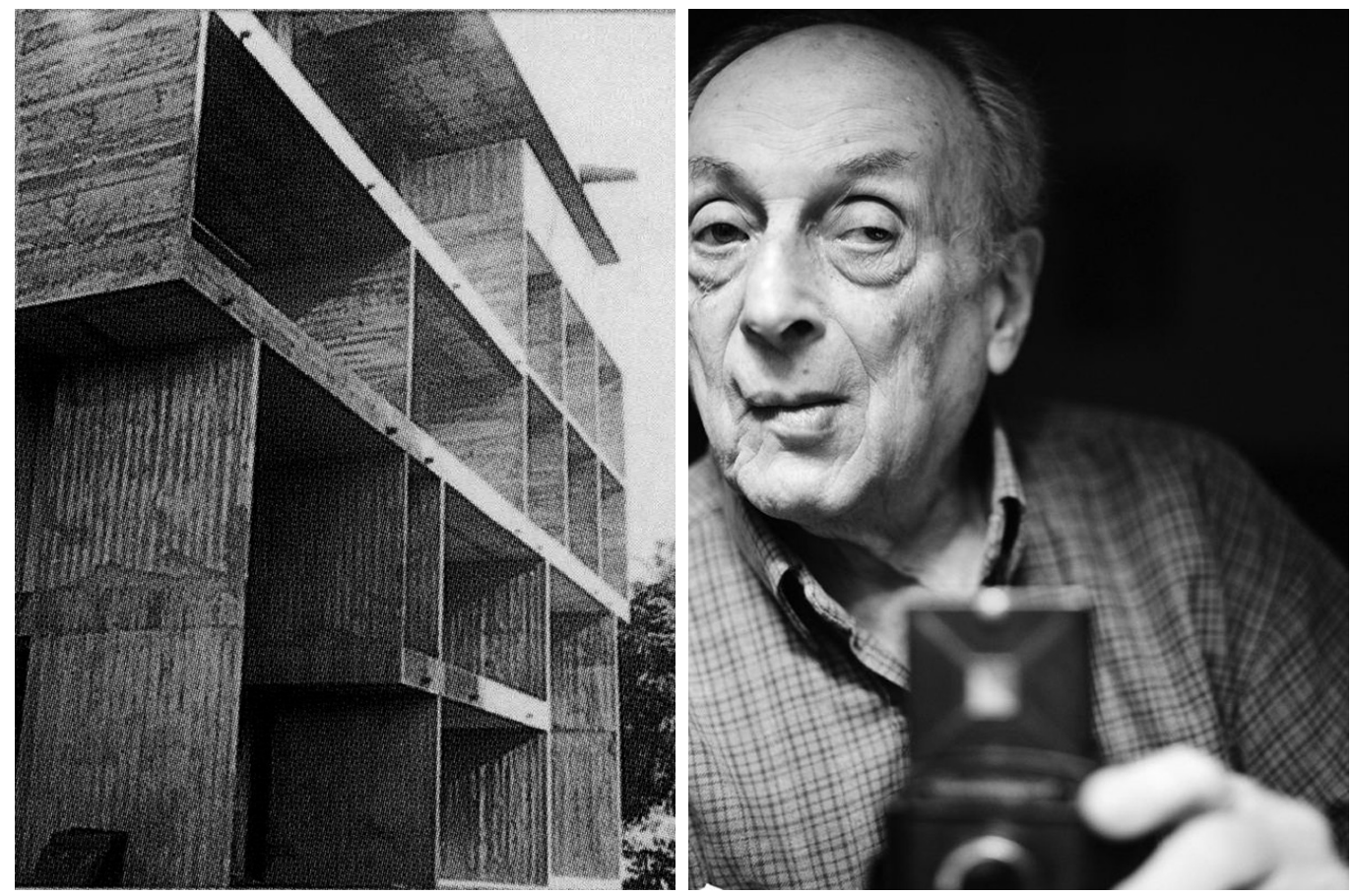

Hervé, now in his 60s, stopped his intense work activity due to a health problem and dedicated himself to travel and small commissions. He died on June 26, 2007 in Paris at the age of 96 , leaving behind a valuable body of work that goes beyond architecture.

\section{The photography of Lucien Hervé}

Famous, as he himself said, for his rigor, and known for his chiaroscuro photography (fig. 5) and the crazy framing he did with scissors, in an interview in 1992 he declared: "I have always photographed in such a way that a photograph should be able to be seen inverted. Because for us it is not the subject that is important, it is not the subject, but essentially the plastic expression", [Bergera 2016, documentary transcript] he also stated "the plastic structure of a photo is the essential element to introduce inner tension. Without a de-
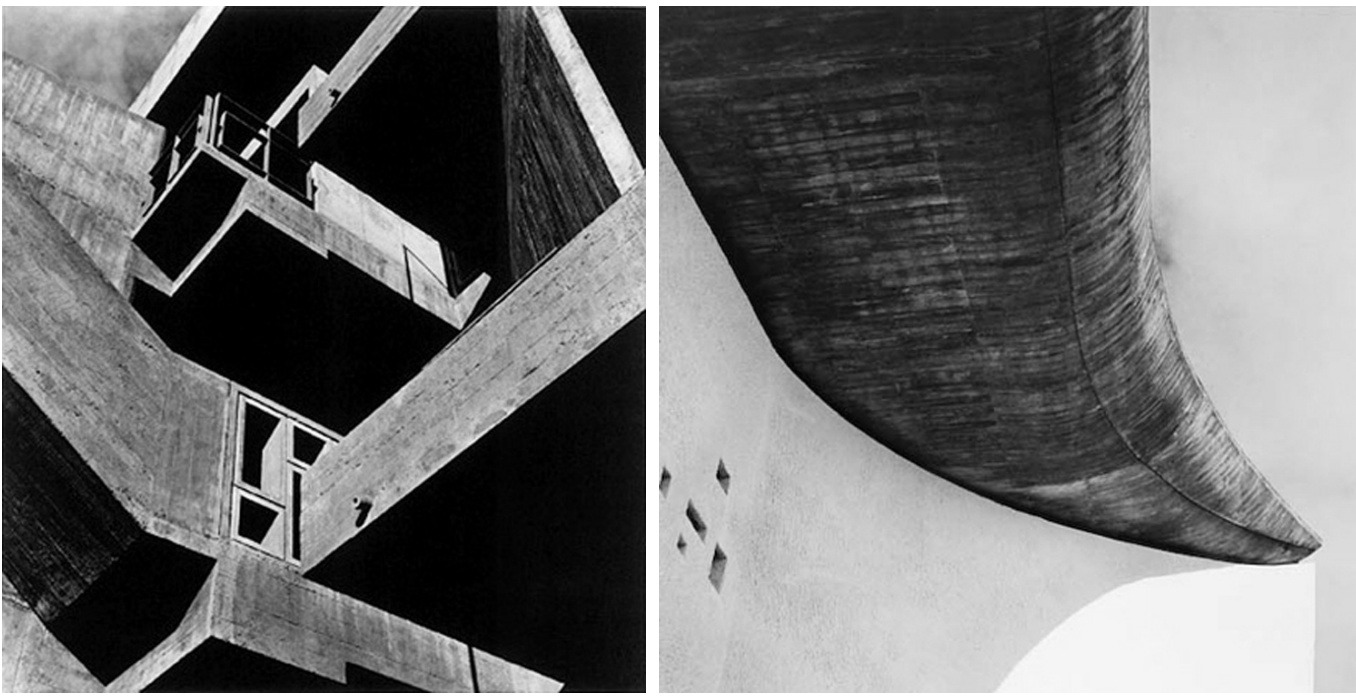

Fig. 5. Claroscuros in the work of Lucien Hervé. Spinners Association, Le (India) 1951. (C) Lucien Hervé.

Fig. 6. Detail of the roof of the church of Ronchamp, Lucien Hervé. (c) Lucien Hervé 
manding and rigorous composition, a photograph is nothing more than an anecdote or a reportage" [Bergera 2016, documentary transcript].

Lucien Hervé's photography cannot be taken as a simple documentation of the photographed elements, but the real attraction of his work lies in the reading he makes of the architect's work. Thus, when we observe his work, in addition to recognizing the photographed element, we are performing the act of looking as if it were Hervé himself (fig. 6).

When Hervé arrived at his studio after a day's work, he would develop the photographs he had taken, classify them and choose the best ones. He would paste them on cardboard and cut them up at will, leaving only the part that most interested him, thus abstracting from the building, but at the same time adding value to it, making it disappear as an object and transforming it into an abstract landscape. He said to himself that his main virtue was rigor and, in the same way that a sculptor discovers sculpture by subtracting stone from a block, Hervé used what he called self-criticism with scissors to eliminate the superfluous in each frame.

With the final result, he made albums, gluing the cut images together to create a compositional sequence, as if it were an architectural promenade on a photographic base. Within the impossibility of photographing movement, architectural photographers do not capture instants but lapses, being the representation, within the paradox of static photography, of "a journey for the gaze that evokes to a certain extent the real spatial perception of the scene represented" [Bergera 2016, p. 136]. Then, the essence of the series of photographs is directly related to the photographed space, being the relationship between the photographs of the sequence itself the one that shows us the nature of the project.

Hervé was one of those unusual photographers with the soul of an architect. His unique way of portraying buildings, fleeing from monumentality and symmetries, his peculiar style of cropped images, of sharp and contrapposto, shadow games, oblique views that end up in frames with a strong perspective and abstract compositions, was what made him stand out from his contemporaries.

There are countless representative images of Hervé's work. However, its importance, leaving aside the mere image, is what it represents. Its essence lies in the form of an architectural reference, whose photographic nature is manifested in a scheme of extreme simplicity that highlights its configuration through a play of light and shadow that the photographer uses on many occasions in a deconstructive way, directing us to more complex and dense visual realms.

\section{The infographic language between time and distance}

The Hutheesing and Chimanbhai villas were two commissions Le Corbusier received to build two houses in Ahmedabad. The first by the president of the association of spinners Surottam Hutheesing and the second by the mayor of the city of Ahmedabad itself. Neither was carried out.

In the projects for the Hutheesing and Chimanbhai villas, the brise-soleil facades, the famous umbrella that flies and covers the construction and the sober exterior geometry that encloses a dynamic section resulting from an interior play of volumes that fly creating courtyards of different heights, stand out.

Both designs were variations on the same basic idea, cubic volumes perforated by deep openings for air and shade, and huge horizontal floating sunshades to protect from sun and rain: what today we would call passive systems of sustainable construction. Le Corbusier composed the facades by arranging the brise-soleil according to the proportions of the Modulor, designed the lower parts of the houses low and shady and, as you went up, the building opened up to the sky and the environment.The brise-soleil and the blind panels of the facades, with their orthogonal geometries, stood out against the meandering interior routes and the occasional oval elements.

The designs for the Chimanbhai (figs. 7, 9, II) and Hutheesing (figs. 8, 10, 12) residences were also intended to give a monumental presence by ennobling the domestic 
Fig. 7.Villa Chimanbhai, Le Ahmedabad (India), 1951. Graphic restitution of the authors.

Fig. 8.Villa Hutheesing, Le Corbusier. Ahmedabad (India), 1951. Graphic restitution of the authors.
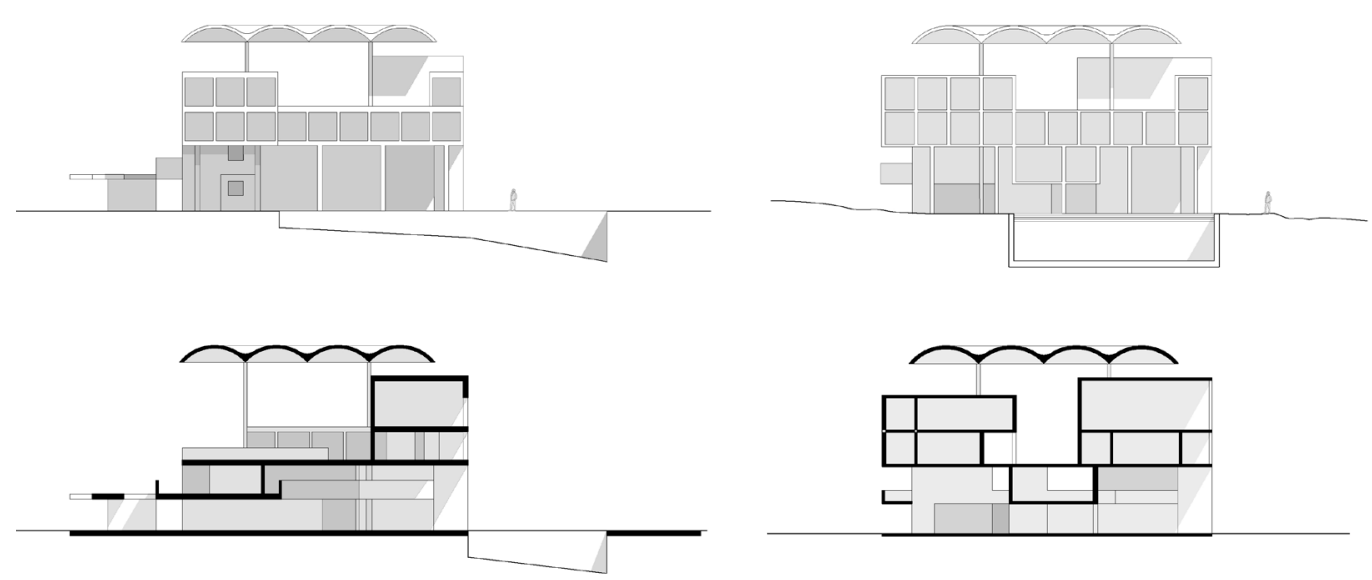

program. Both designs were variations on the same basic idea, cubic volumes pierced by deep openings for air and shade, and huge horizontal floating sunshades to protect from sun and rain.

Le Corbusier composed the facades by arranging the brise-soleil according to the proportions of the Modulor, designed the lower parts of the low, shaded dwellings, and as you went up, the building opened up to the sky and the surroundings. The brise-soleil and the blind panels of the facades, with their orthogonal geometries, stood out against the meandering interior routes and the occasional oval elements.

There were several reasons why these villas never came to fruition, but Le Corbusier rescued both projects looking for inspiration to design the Shodhan villa.

Today the digital media used in the field of architecture have evolved enormously. For the realization of this work, we have previously made a compilation of information on the work of Le Corbusier in India. From this documentation we have selected sketches, texts and, above all, plans to develop a series of surveys of the villas to be represented. Once the surveys were available, a 3D model of the buildings was made with the same CAD program with which the $2 \mathrm{D}$ plans had been drawn up.

After this, the model is exported to a 3D graphics and animation program. This program is used to create the scene that will later become our photograph. Therefore, the materials of which the model is composed are designed and applied, based on the architect's already constructed buildings, the necessary elements and lights of the landscape are placed to give greater verisimilitude to the image and the cameras are placed, looking for the best perspectives and framing, trying to simulate the photograph of Hervé himself. Finally, by slightly retouching the resulting image using a post-production program, we can obtain the 'photograph' we were looking for.
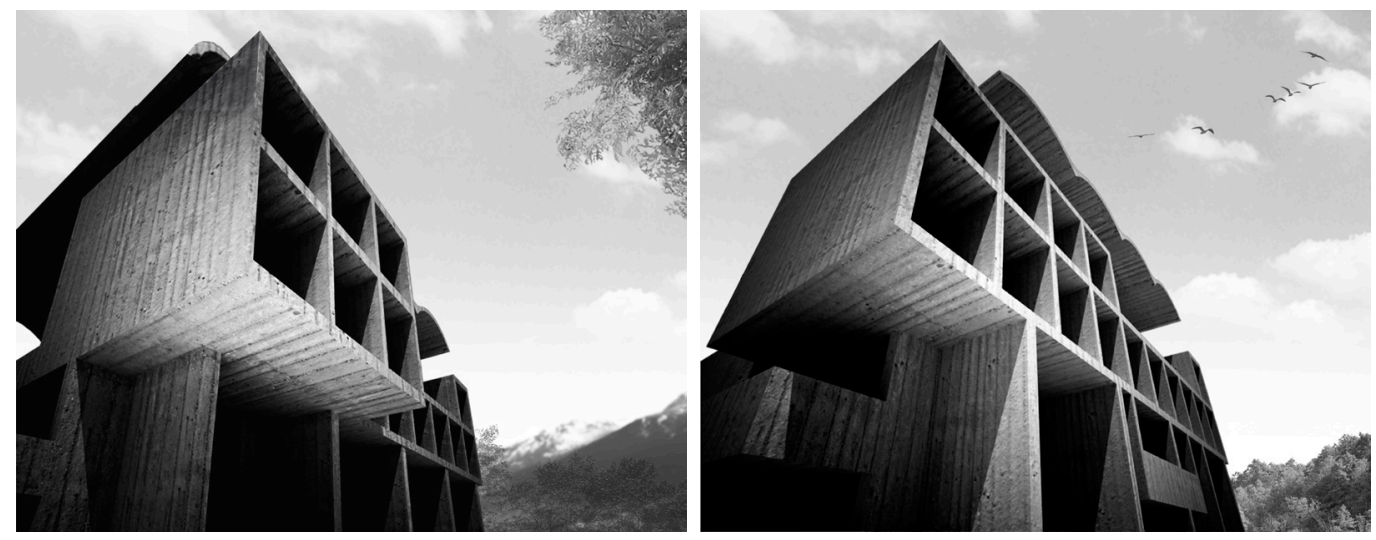
Fig. II. Interior villa infographic.

Fig. 12. Interior villa Hutheesing, Authors infographic.
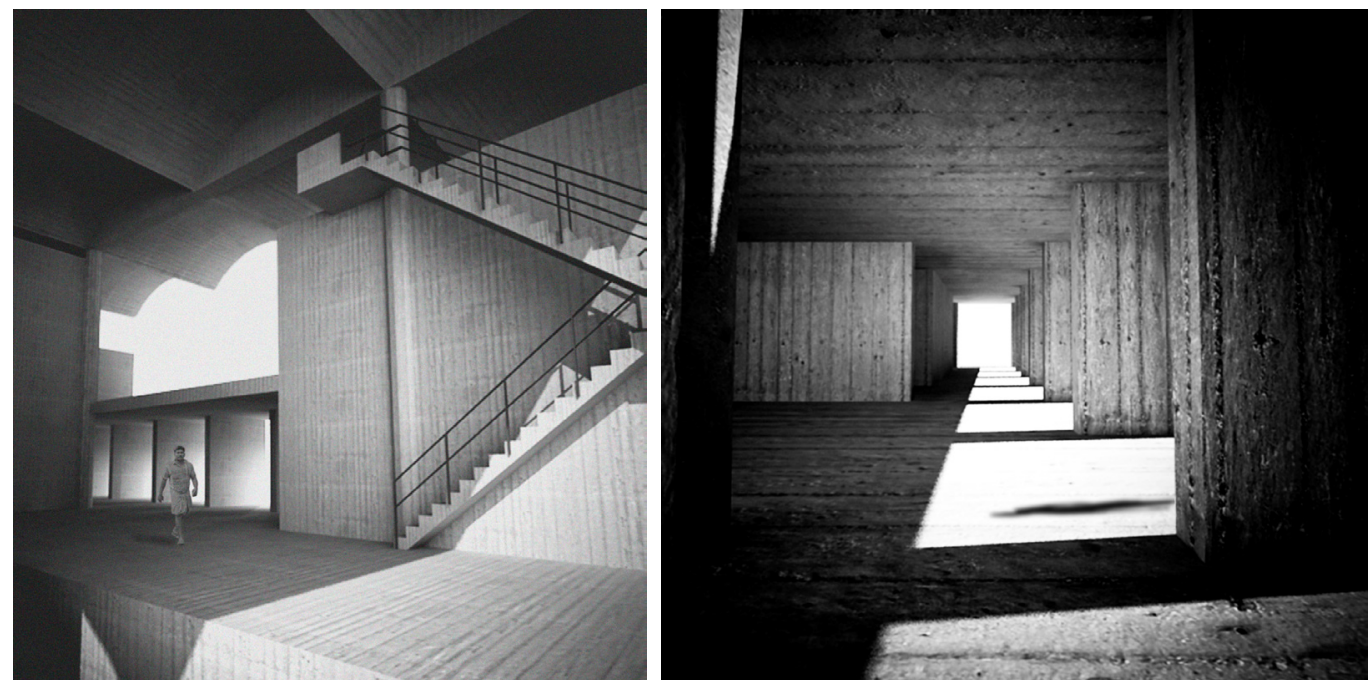

\section{Conclusions}

How technology (infographics) allows us to approach, through graphic language, the distance introduced by time and unbuilt architecture, and to make it tangible and contemporary for us through images and raised plans.

Therefore, we contribute to the knowledge of these unbuilt architectures, both from the rigor of metrics and the more conventional representation of architecture, as well as from the new infographic technologies, which we use to approach those genuine visions of the photographer that the architect himself chose to disseminate his work. As photography served since its origins in the nineteenth century as a new technology and new language to bring architecture throughout the world, shortening distances and bringing cultures closer, we now use this virtual photography of the non-existent, to photograph, through the privileged gaze of Lucièn Hervè, the unbuilt villas of Le Corbusier in India.

\section{Referencias bibliográficas}

Ando T. (200I). Le Corbusier: Houses. Tokyo:Toto.

Andrieux B. (20I I). Le Corbusier - Lucien Hervé, Kontakte. Munich: Schirmer Mosel.

Benton T. (1984). Les villas de Le Corbusier. París: P. Sers.

Bergera I. (2016a). Lucien Hervé: fotógrafo a su pesar. Barcelona: Arquia

Bergera I. (2016b). Sobre fotografía y arquitectura. Madrid: Ediciones Asimétricas.

BoesigerW. (1995). Le Corbusier. Oeuvre complète. 8 vols. Zurich: Girsberger.

Curtis W. J. R. (1987). Le Corbusier, ideas y formas. Madrid: Blume.

Frampton K. (2000). Le Corbusier. Madrid: Editore Akal.

Gonzalez D. (6 de mayo de 20 I 3). Le Corbusier:The last proyect. Metalocus. <https://www.metalocus.es/es/noticias/dionisio-gonzalez-le-corbusier-last-project> (accessed 2021, July 7).

Le Corbusier. (1965). Hacia una arquitectura. Buenos Aires: Poseidón. Original title: Vers une Architecture, 1923.

\section{Authors}

Eduardo Carazo, Universidad de Valladolid, eduardo.carazo.lefort@uva.es

Álvaro Moral, Universidad de Valladolid, alvaro.moral@uva.es

David Mahamud, Universidad de Valladolid, david.mahamud@alumnos.uva.es

To cite this chapter. Carazo Eduardo, Moral Álvaro, Mahamud David (2021). Restitución de las villas no construidas de Le Corbusier en India mediante la mirada de Lucièn Hervè/Restitution of Le Corbusier's Unbuilt Villas in India through the eEyes of Lucièn Hervè. In Arena A Aren M. Mediati D. Raffa P (a cura di). Connettere. Un disegno per annodare e tessere Linguagoi Distanze Tecnologie. Atti del $42^{\circ}$ Convegno Internazionale dei Docenti delle Discipline della Rappresentazionel Connecting. Drawing for weaving relationship Langueges Distances Technologies Proceedings of the 42th International Conference of Representation Disciplines Teachers. Milano: FrancoAngeli, pp. $2137-2150$. 